\title{
PENGEMBANGAN LEMBAR KERJA SISWA \\ MATEMATIKA BERBASIS PENEMUAN TERBIMBING \\ UNTUK SISWA KELAS VII SEKOLAH MENENGAH PERTAMA PADA MATERI SEGIEMPAT
}

\author{
Veta Fitriani', Lusi Eka Afri² \\ 1,2Pendidikan Matematika Universitas Pasir Pengaraian \\ fitrianiveta@gmail.com
}

\begin{abstract}
This study aims to produce valid guided discovery-based math worksheets on rectangular material. This type of research is development research. This research consists of three stages of development, definition, design, and development. This study's subjects were class VII students of SMP Negeri 3 Rambah Hilir in the second semester of the 2019/ 2020 school year. The instrument used in this study was a validation questionnaire sheet. Discovery-based worksheets guide the results of this study. Based on the validity test of the guided discoverybased student worksheet carried out on three validators with several revisions and improvements, the average score of the guided discovery-based student worksheet validation was 3.73 with a very valid category. So it can be concluded that guided discoverybased worksheets are very valid.
\end{abstract}

Keywords: Development, Guided Discovery Based, Quadrilateral

\begin{abstract}
ABSTRAK Penelitian ini bertujuan untuk menghasilkan LKS matematika berbasis penemuan terbimbing yang valid pada materi segiempat. Jenis penelitian yang digunakan adalah penelitian pengembangan. Penelitian ini terdiri dari tiga tahap pengembangan pendefinisian, perancangan dan pengembangan. Subjek penelitian ini adalah siswa kelas VII SMP Negeri 3 Rambah Hilir pada semester II tahun pelajaran 2019/ 2020. Instrumen yang digunakan dalam penelitian ini adalah lembar angket validasi. Hasil penelitian ini LKS berbasis penemuan terbimbing. Berdasarkan uji validitas LKS berbasis penemuan terbimbing yang telah dilakukan kepada tiga orang validator dengan beberapa revisi dan perbaikan maka didapat skor rata-rata hasil validasi LKS berbasis penemuan terbimbing adalah 3,73 dengan kategori sangat valid.
\end{abstract}

Kata-kata Kunci : Pengembangan, Berbasis Penemuan Terbimbing, Segiempat

\section{PENDAHULUAN}

Matematika merupakan salah satu mata pelajaran yang diajarkan pada setiap jenjang pendidikan di Indonesia mulai dari Sekolah Dasar (SD) hingga Sekolah Menengah Atas (SMA) bahkan perguruan tinggi (PT). Matematika juga dijadikan salah satu penentu kelulusan siswa yaitu dengan adanya Ujian Nasional (UN) matematika dalam setiap jenjang pendidikan. Hal ini dilaksanakan karena matematika merupakan ilmu pengetahuan yang penting sebagai pengantar ilmuilmu pengetahuan yang lain. Oleh sebab itu pembelajaran matematika harus 
dilaksanakan dengan baik agar apa yang diinginkan dapat tercapai dengan maksimal.

Guru selalu berupaya agar siswa dapat menguasai materi dan memahami konsepkonsep matematika sehingga pembelajaran berjalan dengan maksimal. Upaya tersebut dapat dilakukan guru dalam pembelajaran di sekolah, dimana dalam pembelajaran terdapat proses belajar mengajar antara guru dengan siswa. Berdasarkan hal tersebut maka dalam proses pembelajaran siswa berperan menjadi subjek bukan objek pembelajaran, siswa dibebaskan untuk berperan aktif karena pembelajaran di kelas akan lebih bermakna ketika pengetahuan dicari dan ditemukan siswa itu sendiri.

Pembelajaran bermakna sebagai suatu proses yang tidak terlepas dari komponenkomponen lain yang saling berinteraksi didalamnya. Salah satu komponen dalam proses tersebut adalah sumber belajar. Menurut Hamdani (Surbakti dkk, 2016) sumber belajar merupakan segala sesuatu yang dapat digunakan dalam bentuk media untuk membantu siswa dalam belajar, bentuknya tidak terbatas misalnya berbentuk cetakan, video, kombinasi dari berbagai format yang dapat digunakan oleh siswa ataupun guru. Salah satu bahan ajar yang dapat digunakan untuk mendukung proses pembelajaran di sekolah adalah berupa bahan cetak seperti Lembar Kerja Siswa (LKS).

Menurut Setiyorini (2014) lembar kerja siswa adalah lembaran-lembaran yang digunakan siswa sebagai pedoman dalam proses pembelajaran, serta berisi tugas yang dikerjakan oleh siswa baik berupa soal maupun kegiatan yang akan dilakukan siswa. Sedangkan menurut Prastowo (Dewi, 2019) lembar kerja siswa (LKS) adalah materi ajar yang sudah dikemas sedemikian rupa, sehingga siswa diharapkan dapat mempelajari materi ajar tersebut secara mandiri dan dapat menemukan arahan yang terstruktur untuk memahami materi yang diberikan. Mugiono (Sholehah, 2016) mengemukakan LKS adalah suatu cara penyajian materi yang mengarahkan siswa untuk menemukan konsep, teorema, rumus, pola, aturan, dan sebagainya, dengan melakukan dugaan, perkiraan, coba-coba ataupun usaha lainnya.

Berdasarkan hasil wawancara dengan guru matematika di SMP Negeri 3 Rambah Hilir bahwa dalam pembelajaran di sekolah dilakukan dengan menggunakan buku paket kurikulum 2013 dan LKS dari penerbit. Namun, LKS yang digunakan dalam pembelajaran menyajikan materi secara langsung tanpa dilengkapi dengan langkah-langkah yang terstruktur untuk menemukan suatu konsep dasar. Sedangkan kurikulum 2013 merupakan pembelajaran yang berpusat pada siswa. Dengan kata lain LKS dari penerbit belum sesuai dengan pembelajaran kurikulum 2013. LKS langsung menyajikan konsep matematika sehingga siswa tidak terlibat aktif dalam proses pembelajaran di kelas.

Upaya yang dapat dilakukan agar proses pembelajaran dapat tercapai dengan maksimal sebaiknya LKS didesain berdasarkan prinsip pembelajaran yang mengajak siswa untuk berpikir aktif, salah satunya yaitu menggunakan prinsip pembelajaran 
penemuan terbimbing. Dengan demikian, siswa diharapkan benar-benar aktif dalam menemukan dan membangun konsepnya sendiri. Selain itu, selama proses penggunaan LKS matematika diperlukan model pembelajaran yang disesuaikan dengan prinsip pembelajaran LKS yaitu model pembelajaran penemuan terbimbing. Menurut Jerome (Sitorus, 2016) model penemuan terbimbing adalah pembelajaran yang menyarankan agar siswa berpartisipasi aktif dalam memperoleh pengalaman dan melakukan penerapan untuk menemukan konsep. Sani (Hidajat dan Hidajat, 2018) berpendapat bahwa penemuan terbimbing adalah strategi pembelajaran yang dapat meningkatkan kreatifitas siswa melalui proses penemuan yang dilakukannya sendiri. Menurut Syah (Suyadi, 2017) adapun langkah- langkah dalam model pembelajaran penemuan terbimbing terdiri dari enam tahapan antara lain: stimulation (pemberian rangsangan), problem statement (identifikasi masalah), data collection (pengumpulan data), data processing (pengolahan data), verification (pemeriksaan), dan generalization (penarikan kesimpulan).

Penemuan terbimbing melibatkan siswa dalam menjawab pertanyaan-pertanyaan guru. Siswa melakukan penemuan dan hipotesis sedangkan guru membimbing mereka ke arah yang benar atau tepat dan mengarahkan siswa kepada titik kesimpulan. Hal ini diharapkan dapat memberikan kesempatan kepada siswa dalam memahami konsep matematika melalui keterlibatan aktif pada saat melakukan kegiatan penemuan, menyusun hipotesis, menguji hipotesis serta menarik kesimpulan. Berdasarkan uraian latar belakang diatas, maka tujuan penelitian ini yaitu menghasilkan LKS matematika berbasis penemuan terbimbing untuk siswa kelas VII sekolah menengah pertama yang valid pada materi segiempat.

\section{METODE PENELITIAN}

Jenis penelitian yang dilakukan adalah penelitian pengembangan (Research and Development). Menurut Sugiyono (2012) metode penelitian dan pengembangan adalah metode penelitian yang digunakan untuk menghasilkan produk tertentu dan menguji keefektifan produk tersebut.Pengembangan lembar kerja siswa (LKS) matematika berbasis penemuan terbimbing ini menggunakan 4-D. Tahap-tahap pengembangan tersebut adalah pendefinisian (Define), perancangan (Design), pengembangan (Develop) dan penyebaran (Desseminate). Tetapi dalam penelitian ini telah dimodifikasi menjadi 3-D yang terdiri dari tiga yaitu tahap pendefinisian (Define), perancangan (Design) dan pengembangan (Develop), karena keterbatasan waktu dan biaya (Sumaji, 2015). Prosedur pengembangan yang digunakan pada penelitian ini sesuai dengan model pengembangan 4-D yang telah dimodifikasi menjadi 3-D.

Tahap pendefinisian dilakukan dengan menganalisis pada 3 aspek yaitu analisis terhadap kurikulum, analisis siswa dan analisis kebutuhan siswa. Analisis kurikulum dilakukan pemantauan tingkat pencapaian tujuan pendidikan matematika dimana Pemerintah membentuk Badan Standar Nasional Pendidikan (BSNP) yang menyusun standar kompetensi dan kompetensi dasar Satuan pendidikan harus mengembangkan dan menyusun indikator-indikator pencapaian kompetensi untuk setiap mata pelajaran berdasarkan standar kompetensi dasar yang ditetapkan BSNP. 
Selanjutnya adalah menganalisis konsep-konsep yang esensial yang diajarkan pada semester II kelas VII SMP. Analisis konsep ini memberikan gambaran umum tentang metode dan pendekatan pembelajaran yang sesuai digunakan serta permasalahan yang akan disajikan. Hasil analisis konsep juga memberikan gambaran tentang materi apa saja yang dapat disajikan melalui model penemuan terbimbing yang akan digunakan pada lembar kerja siswa. Kemudian analisis siswa dilakukan untuk mengetahui karakteristik siswa. Karakteristik ini meliputi jumlah siswa, usia siswa dan karakter siswa. Untuk keperluan penelitian ini peneliti mengambil kelas VII SMP Negeri 3 Rambah Hilir sebagai subjek uji coba. Analisis siswa dilakukan sebagai landasan dalam merancang pembelajaran melalui LKS yang akan dikembangkan. Selanjutnya analisis kebutuhan siswa dilakukan untuk mengetahui masalah yang mendasari terjadinya ketimpangan dalam proses pembelajaran yang berhubungan dengan peran dan penggunaan LKS dalam pembelajaran. Selain itu analisis juga dilakukan terhadap bahan ajar yang digunakan oleh guru maupun yang dijual dipasaran. Analisis ini yang mendasari perlunya pengembangan LKS berbasis penemuan terbimbing.

Tahap perancangan adalah tahap untuk penyusunan LKS berbasis penemuan terbimbing. Penyusunan LKS berbasis penemuan terbimbing disesuaikan dengan materi segiempat kelas VII dan model berbasis penemuan terbimbing. Tahap pengembangan ini menghasilkan LKS berbasis penemuan terbimbing. Tahap ini terdiri dari beberapa tahapan: Validasi LKS yang sudah dirancang dikonsultasikan dan didiskusikan dengan beberapa orang pakar. Kegiatan validasi dilakukan dengan mengisi lembar validasi LKS hingga diperoleh LKS yang valid dan layak untuk digunakan. Tahap revisi dilakukan apabila hasil penilaian validator ditemukan beberapa bagian yang perlu diperbaiki. LKS yang telah direvisi diberikan kembali kepada validator untuk didiskusikan lebih lanjut apakah produk LKS sUdah valid atau sudah layak.

Pengembangan LKS hanya dilakukan sampai pada tahap validasi saja. Hal ini disebabkan oleh keterbatasan waktu dan keadaan pada saat melakukan pengembangan LKS. Jenis data yang diperoleh dari penelitian ini yaitu data primer yang diambil langsung dari lembaran validasi dari masing- masing validator LKS yang diambil dari angket dosen matematika dan guru matematika. Teknik pengumpulan data adalah suatu cara yang digunakan untuk mengumpulkan data yang digunakan. Pada penelitian ini teknik pengumpulan data yang digunakan adalah teknik non tes yaitu angket. Angket yang digunakan adalah angket validasi LKS, angket ini menggunakan skala likert antara lain: 1) Sangat tidak setuju; 2) Tidak setuju; 3) Kurang setuju; 4) Setuju; 5) Sangat setuju.

Instrumen pengumpulan data yang digunakan dalam penelitian ini adalah instrumen kevalidan LKS berbasis penemuan terbimbing. Validasi dilakukan untuk mengetahui keabsahan LKS yang telah dirancang yaitu LKS berbasis penemuan terbimbing. Lembar validasi LKS berisi penilaian yang terdiri atas aspek didaktik, isi, bahasa dan tampilan (layout). Validasi dilakukan kepada 3 orang validator. 
Data ini dianalisis dengan analisis deskriptif. Data yang dikumpulkan dalam penelitian ini adalah hasil validitas LKS oleh pakar. Hasil validasi dari validator terhadap seluruh aspek yang dinilai disajikan dalam bentuk tabel. Analisis dilakukan dengan menggunakan skala likert. Berikut rumus untuk menghitung nilai skor rata-rata hasil validasi:

$$
\text { nilai }=\frac{\text { jumlah skor validasi keseluruhan responden }}{\text { banyak pertanyaan } \mathrm{x} \text { banyak responden }}
$$

Rata-rata yang didapatkan dikonfirmasikan dengan kategori yang ditetapkan. Cara mendapatkan kategori tersebut dengan menggunakan aturan berikut: Skor maksimum 4 dan skor minimum 0, maka rentang skor adalah $4-0=4$. Karena penilaian akan dibagi dalam 5 kelas, maka panjang kelas intervalnya adalah $4: 5=$ 0.8. Dengan mengikuti prosedur di atas penilaian validitas dapat diinterpretasikan dengan kategori sebagai berikut:

Tabel 1. Interpretasi Data Validasi

\begin{tabular}{cc}
\hline Interval & Kriteria \\
\hline $0.0 \leq$ Nilai $\leq 0.8$ & Tidak Valid \\
\hline $0.8<$ Nilai $\leq 1.6$ & Kurang Valid \\
\hline $1.6<$ Nilai $\leq 2.4$ & Cukup Valid \\
\hline $2.4<$ Nilai $\leq 3.2$ & Valid \\
\hline $3.2<$ Nilai $\leq 4.0$ & Sangat Valid \\
\hline Sumber: Isharyadi dan Ario (2018)
\end{tabular}

Jadi dapat disimpulkan bahwa LKS dikatakan valid jika rata-rata yang diperoleh $\geq 2.4$.

\section{HASIL DAN PEMBAHASAN}

Penelitian ini merupakan pengembangan LKS berbasis penemuan terbimbing untuk kelas VII SMP. Tahap awal pengembangan LKS adalah tahap pendefinisian yang meliputi analisis kurikulum, analisis siswa dan analisis kebutuhan siswa. Pada tahap ini memerlukan buku BSNP untuk menganalisis kurikulum, data siswa dilakukan untuk menganalisis siswa seperti jumlah siswa, usia siswa, dan karakter siswa.

Tahap pendefinisian adalah tahap awal yang harus dilakukan sebelum mengembangkan LKS berbasis penemuan terbimbing. Tahap ini sebagai landasan dalam mengembangkan LKS berbasis penemuan terbimbing yang dibutuhkan. Pada tahap ini ada beberapa analisis yang dilakukan yaitu analisis kurikulum, analisis siswa dan analisis kebutuhan siswa. Penjelasan dari analisis-analisis tersebut adalah sebagai berikut:

1. Analisis Kurikulum

Kegiatan awal yang dilakukan dalam pengembangan LKS yaitu analisis kurikulum. Hasil analisis kurikulum yang digunakan sekarang adalah kurikulum 2013, dimana dalam kurikulum ini menuntut pembelajaran berpusat pada siswa. Kurikulum 2013 difokuskan pada pembentukan kompetensi dan karakter siswa, 
berupa panduan pengetahuan, keterampilan dan sikap yang dapat didemonstrasikan siswa sebagai wujud pemahaman terhadap konsep yang dipelajarinya secara kontekstual. Tujuan tersebut sesuai dengan metode penemuan terbimbing dimana siswa dapat memahami konsep tersebut dengan bimbingan guru dalam menemukan konsep pembelajaran matematika.

Analisis kurikulum juga dilakukan terhadap Kompetensi Dasar (KD), indikator, dan materi segiempat kelas VII untuk Sekolah Menengah Pertama (SMP). Analisis ini menjadi pedoman dalam mengembangkan LKS berbasis penemuan terbimbing untuk kelas VII SMP. Berdasarkan Permendikbud No. 24 Tahun 2016 hasil analisis kurikulum materi segiempat untuk siswa kelas VII SMP semester II dengan kompetensi dasar yaitu : 3.11 Mengaitkan rumus keliling dan luas untuk berbagai jenis segiempat (persegi, persegi panjang, belahketupat, jajargenjang, trapesium, dan layang-layang) dan segitiga; 4.11 Menyelesaikan masalah kontestual yang berkaitan dengan luas dan keliling segiempat (persegi, persegi panjang, belahketupat, jajargenjang, trapesium, dan layang-layang) dan segitiga.

Kompetensi inti dan kompetensi dasar yang telah ditentukan pada kurikulum 2013 dijabarkan ke dalam indikator-indikator pencapaian kompetensi. Indikatorindikator tersebut dijadikan sebagai acuan dalam pengembangan LKS berbasis penemuan terbimbing materi segiempat untuk siswa kelas VII SMP.

Analisis terhadap materi maka yang perlu disajikan yaitu LKS berbasis penemuan terbimbing. LKS berbasis penemuan terbimbing ini akan memudahkan siswa menemukan konsep sendiri dalam memahami jenis-jenis segiempat beserta sifatnya, menemukan rumus keliling dan luas segiempat (persegi panjang dan persegi), karena LKS berbasis penemuan terbimbing ini tidak menyajikan konsep secara langsung melainkan dengan beberapa tahapan yakni: stimulation (pemberian rangsangan), problem statement (identifikasi masalah), data collection (pengumpulan data), data processing (pengolahan data), verification (pemeriksaan) dan generalization (kesimpulan).

\section{Analisis Siswa}

Hasil analisis siswa yaitu siswa kelas VII menjadi subjek penelitian dalam uji coba LKS berbasis penemuan terbimbing. Subjek penelitian tersebut adalah siswa kelas VII SMP Negeri 3 Rambah Hilir tahun ajaran 2019/2020 yang terdiri dari 27 siswa, 13 laki-laki dan 14 perempuan. Secara umum, usia siswa kelas VII adalah berkisar antara 12-13 tahun.

Berdasarkan pengamatan di kelas VII SMP Negeri 3 Rambah Hilir siswa sering bercerita dan berdiskusi dengan teman disekitarnya mengenai hal yang tidak berhubungan dengan materi pembelajaran, sehingga siswa tidak fokus terhadap pembelajaran yang diberikan oleh guru. Siswa hanya menghafal rumus tanpa memahami konsep penggunaan rumus, sehingga diberi soal beragam siswa mengalami kesulitan. Siswa juga hanya mendengar penjelasan materi dari guru sehingga tidak aktif dalam proses pembelajaran. Saat diberikan latihan 
siswa lebih suka menunggu hasil jawaban temannya atau menyontek daripada harus mengerjakannya sendiri.

Berdasarkan karakter yang ditemukan maka peneliti merasa perlu mengembangkan LKS berbasis penemuan terbimbing yang dapat mengakomodasi karakter yang dimiliki siswa tersebut pada arah positif dalam pembelajaran. LKS berbasis penemuan terbimbing merupakan pembelajaran yang dapat membuat siswa aktif dalam mengikuti pelajaran. Dalam pembelajaran dengan menggunakan LKS berbasis penemuan terbimbing siswa akan belajar secara berkelompok dan berdiskusi dalam menemukan konsep dengan bimbingan guru sesuai langkah-langkah penemuan terbimbing, sehingga aktivitas ini dapat memfasilitasi karakter siswa yang suka berdiskusi.

\section{Analisis Kebutuhan Siswa}

Pengamatan yang dilakukan di kelas VII SMP Negeri 3 Rambah Hilir terlihat pada saat proses pembelajaran matematika di kelas guru dan siswa hanya menggunakan buku paket dari Pemerintah dan LKS dari penerbit. Proses pembelajaran matematika pada kelas VII guru masih menggunakan metode pembelajaran biasa, yaitu guru menjelaskan konsep sehingga siswa kurang aktif dalam proses pembelajaran.

Buku paket yang digunakan dalam proses pembelajaran belum bisa membuat siswa termotivasi karena buku paket tergolong sulit untuk dipahami dalam segi materi, dan bahasa yang digunakan sulit dimengerti siswa. Buku paket yang tersedia juga terbatas sehingga dalam menggunakan buku tersebut siswa harus secara bergantian. Kemudian LKS yang digunakan menyajikan materi secara langsung sehingga siswa tidak terbiasa untuk menemukan konsep matematika secara mandiri.

Hasil analisis yang telah dilakukan menunjukkan bahwa siswa membutuhkan LKS sebagai bahan ajar yang mampu membimbing siswa untuk menemukan suatu konsep secara mandiri. Hal ini juga menumbuhkan berpartisipasi aktif dalam pembelajaran matematika. Maka LKS yang dapat memfasilitasi kebutuhan siswa tersebut adalah LKS berbasis penemuan terbimbing. LKS berbasis penemuan terbimbing merupakan lembaran-lembaran berisi tugas yang harus dikerjakan siswa dengan berpedoman berupa pertanyaan-pertanyaan yang membimbing siswa menyelesaikan masalah untuk menemukan konsep pembelajaran.

Tahapan perancangan LKS berbasis penemuan terbimbing ini dilakUkan secara sistematik, mulai dari sampul hingga isi. Judul LKS disebut cover terdiri dari judul LKS guna memberikan gambaran materi yang terdapat pada LKS. Bagian isi meliputi Kompetensi dasar dan indikator yang menyatakan kemampuan siswa yang akan dicapai pada pembelajaran, petunjuk belajar yang berfungsi untuk menuntun siswa sebelum melaksanakan pembelajaran dan isi materi terdapat materi yang harus dipelajari sesuai dengan langkah-langkah penemuan terbimbing yaitu simulation, problem statement, data collection, data processing, verification, dan generalization. 
Perangkat pembelajaran yang dirancang adalah LKS berbasis penemuan terbimbing. LKS berperan sebagai bahan ajar bagi siswa untuk menemukan konsep pelajaran sebagai saran siswa berlatih soal sesuai konsep yang telah dipelajari. LKS terdiri dari 4 aktivitas untuk 4 kali pertemuan yang dibentuk dalam satu buku tanpa terpisah-pisah antara aktivitas 1, 2, 3 dan 4. Berikut tampilan LKS yang telah disusun disajikan pada Gambar 1.
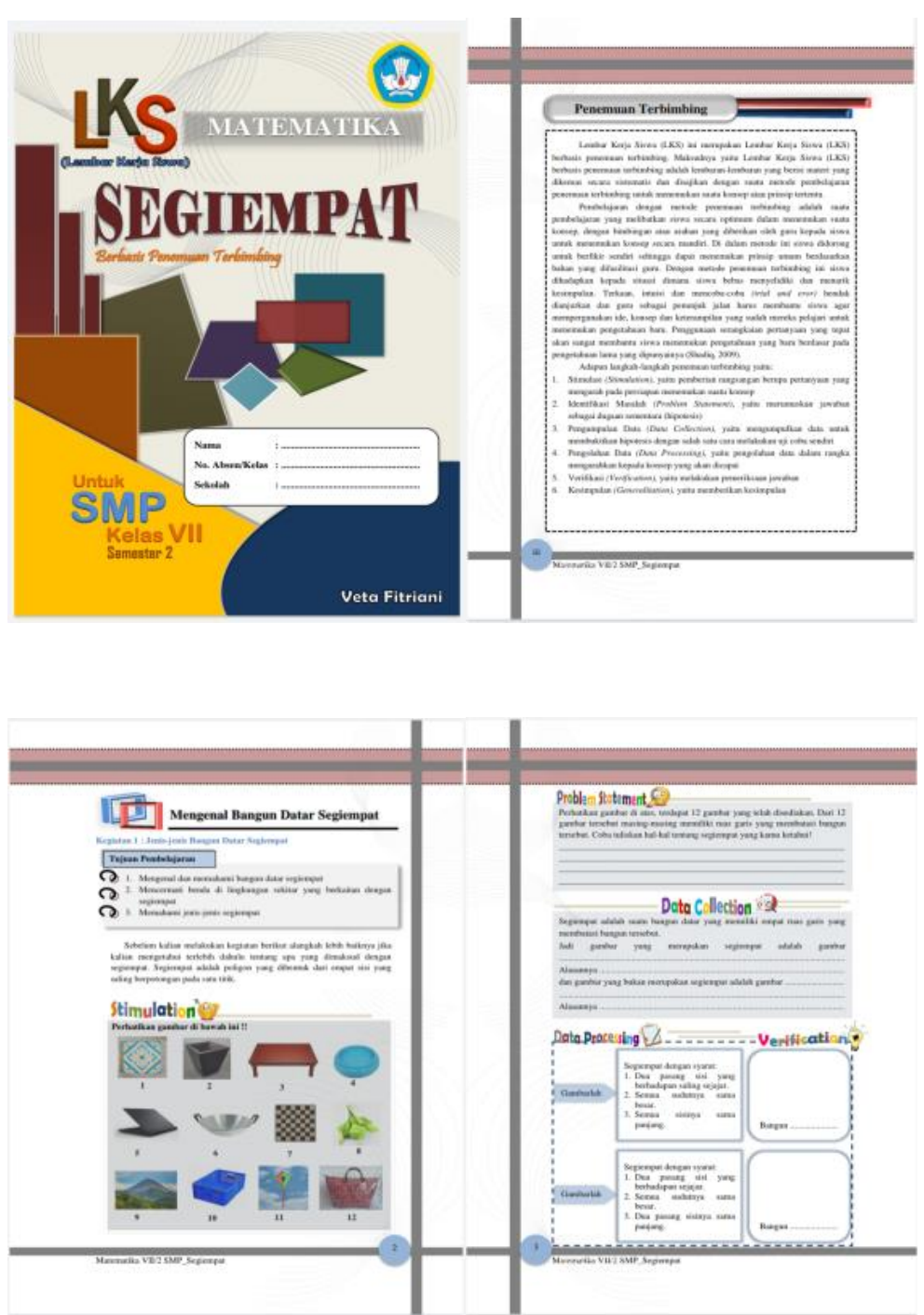

Gambar 1. Contoh Tampilan LKS

Tahap yang dilakukan setelah tahap perancangan LKS berbasis penemuan terbimbing adalah mengembangkan LKS tersebut untuk mengetahui validitas.

Berdasaran analisis dari keempat aspek penilaian validitas LKS berbasis penemuan terbimbing di atas maka diperoleh penilaian hasil validasi keseluruhan. Hasil validasi LKS berbasis penemuan terbimbing keseluruhan disajikan pada tabel 2. 
Tabel 2. Hasil Validasi LKS Berbasis Penemuan Terbimbing Secara Keseluruhan

\begin{tabular}{ccc}
\hline No & Aspek yang dinilai & Rata-rata penilaian \\
\hline 1. & Didaktik & 3.83 \\
\hline 2. & Isi & 3.52 \\
\hline 3. & Bahasa & 3.78 \\
\hline 4. & Tampilan & 3.80 \\
\hline \multicolumn{2}{c}{ Rata-rata keseluruhan aspek } & 3.73 \\
\hline & Kategori & Sangat Valid
\end{tabular}

Dari Tabel 2, terlihat skor rata-rata hasil validasi keseluruhan LKS berbasis penemuan terbimbing adalah 3.73 dengan kategori sangat valid. Dengan demikian dapat disimpulkan LKS berbasis penemuan terbimbing sangat valid. Peneliti telah melakukan pengembangan terhadap perangkat pembelajaran dengan semaksimal mungkin. Namun dalam proses tersebut terjadi kekurangan yang merupakan keterbatasan penelitian ini. Keterbatasan tersebut adalah sebagai berikut:

1. Lembar kerja siswa ini hanya terfokus pada materi segiempat saja khususnya bangun datar persegi dan persegi panjang.

2. Peneliti hanya melakukan pengembangan LKS sampai pada tahap validasi saja. Hal ini disebabkan oleh keterbatasan waktu dan keadaan pada saat melakukan pengembangan LKS ini.

3. Pemberlakuan social distancing di Indonesia membuat segala aktifitas terbatasi termasuk aktifitas di lembaga-lembaga pendidikan yang sementara ditutup akibat adanya virus covid-19 yang mewabah

\section{KESIMPULAN DAN SARAN}

Penelitian ini merupakan penelitian pengembangan yang menghasilkan LKS berbasis penemuan terbimbing. Berdasarkan uji validitas LKS berbasis penemuan terbimbing yang telah dilakukan oleh tiga orang validator dengan beberapa revisi dan perbaikan maka didapat skor rata-rata 3.73 dengan kategori sangat valid. Jadi dapat disimpulkan bahwa LKS berbasis penemuan terbimbing ini sudah sangat valid. Beberapa saran yang diberikan oleh peneliti berdasarkan kesimpulan penelitian ini yaitu sebagai berikut:

1. Diharapkan LKS ini dimanfaatkan oleh siswa dalam proses pembelajaran matematika.

2. Bagi guru matematika kelas VII dan peneliti lainnya disarankan untuk mengembangkan LKS berbasis penemuan terbimbing pada materi lainnya. 


\section{DAFTAR PUSTAKA}

Depdiknas. 2016. Peraturan Menteri Pendidikan dan Kebudayaan Nomor 24 tahun 2016 tentang Kompetensi Inti dan Kompetensi Dasar Matematika SMP/MTs. Jakarta: Depdiknas.

Dewi, R. 2019. Pengembangan Lembar Kerja Siswa (LKS) Menggunakan Model Learning Cycle dengan Pendekatan Saintifik Materi Himpunan kelas VII SMP. Jurnal. (FKIP)

Hidajat, F. A., \& Hidajat, B. I. 2018. Discovery Chanel: Penelitian dan Pengembangan Lembar Kerja Siswa (LKS) Matematika Berbasis Penemuan Terbimbing Pada Materi Bangun Datar. Prosiding Semnas PPM 2018, 1(1), 185-191.

Isharyadi, R., \& Ario, M. 2018. Pengembangan Modul berbantuan Geogebra pada perkuliahan geometri transformasi. Guru Tua: Jurnal Pendidikan dan Pembelajaran, 1 (1).

Setiyorini, E. 2014. Pengembangan Lembar Kerja Siswa (LKS) Untuk Meningkatkan Hasil Belajar Materi Pokok Bangun Ruang Sisi Datar Kelas VIII SMP Negeri 1 Boyolangu Tulungagung Tahun Pelajaran 2013-2014.

Sholehah, S. 2016. Pengembangan Lembar Kerja Siswa (Lks) Berbasis Contextual Teaching Learning (CTL) Materi Himpunan Kelas VII SMP. Jurnal IImiah Mahasiswa FKIP Prodi Matematika, 2(1)

Sitorus, R. 2016. Pengembangan Lembar Kerja Siswa Matematika Berbasis Penemuan Terbimbing Untuk Siswa Kelas VIII SMP Materi Lingkaran. Jurnal IImiah Mahasiswa FKIP Prodi Matematika, 2(1)

Sugiyono. 2012. Metode Penelitian Pendidikan Pendekatan Kuantitatif, Kualitatif, dan R\&D. Bandung: Alfabeta

Sumaji. 2015. Pengembangan Perangkat Pembelajaran Matematika dengan Model Pembelajaran Pemecahan Masalah untuk Meningkatkan Kemampuan Penalaran Matematis. Prosiding. Makalah dipresentasikan dalam Konferensi Nasional Penelitian Matematika dan Pembelajarannya. Universitas Muhammadiyah Surakarta.

Surbakti, E. 2016. Pengembangan LKS Matematika Berbasis Penemuan Terbimbing Siswa Kelas VII SMP Materi Bangun Datar Segi Empat. Jurnal Pendidikan Matematika. Universitas Pasir Pengaraian

Suyadi, V. R. 2017. Pengembangan Lembar Kerja Siswa Berbasis Penemuan Terbimbing Untuk Memfasilitasi Kemampuan Komunikasi Matematis Siswa Sekolah Menengah Pertama. Skripsi. Universitas Islam Negeri Sultan Syarif Kasim Riau. 